\title{
Meta
}

Journal des traducteurs

Translators' Journal

\section{Reid, Hubert (1994) : Dictionnaire du droit québécois et canadien (avec lexique anglais-français), Montréal, Wilson \& Lafleur Ltée, 770 p., ISBN : 2-89127-306-0}

\section{Wallace Schwab}

Volume 40, numéro 4, décembre 1995

URI : https://id.erudit.org/iderudit/004072ar

DOI : https://doi.org/10.7202/004072ar

Aller au sommaire du numéro

Éditeur(s)

Les Presses de l'Université de Montréal

ISSN

0026-0452 (imprimé)

1492-1421 (numérique)

Découvrir la revue

Citer ce compte rendu

Schwab, W. (1995). Compte rendu de [Reid, Hubert (1994) : Dictionnaire du droit québécois et canadien (avec lexique anglais-français), Montréal, Wilson \& Lafleur Ltée, 770 p., ISBN : 2-89127-306-0]. Meta, 40(4), 674-677.

https://doi.org/10.7202/004072ar d'utilisation que vous pouvez consulter en ligne. 
REID, Hubert (1994): Dictionnaire de droit québécois et canadien lavec lexique anglais-franşais), Montréal, Wilson \& Lafleur Ltée. 770 p.. ISBN: 2-89127-306-0.

For information on Civil Procedure in Quebec law, reference works by Professor Hubert Reid have become the bench mark for legal documentation in Quebec and Canada for longer than the professor himself would care to admil. Undaunted by the novelty of new challenges, this already prolific author has charted an adventuresome course into the 
field of legal terminology by unveiling a major achievement, namely his Dictionnaire de droit québécois et canadien, an imposing collection of 8,500 definitions of French language terms currently used in Quebec and Canadian law. The dictionary also includes many Latin and English terms as well as frequently used abbreviations. As a general purpose reference manual, it aims at responding to the needs of legal scholars and practitioners in general. plus those of secretaries. students, translators and anyone else called upon to draft or interpret legal material.

Despite its careful lexicographic presentation. the reader is immediately impressed by the book's ease of consultation. Each entry is presented as follows: Headwords or expressions are listed in the singular (excepting instances where usage requires the plural), followed by the grammatical category and gender. In separate paragraphs, one or more definitions are proposed depending on the number of meanings to be illustrated. This basic information is then complemented with the following add-ons as need be:

- An example providing a concrete illustration of the definition content :

- An explanatory note informing the reader of various specific aspects of the defined term;

- Synonym(s) to call attention to interchangeable forms;

- Comparison(s) to relate the term to other relevant words or expressions;

- An English language translation of the defined term.

As indicated by the author in his introduction, the contents of the Dictionnaire de droit québécois et canadien originate in substantive law, mainly from current legislation but also from important legislative pieces of the past whose significance must not he neglected. Professor Reid rightfully warns readers of the hazards arising from the impact of the law as it evolves (for instance: the new Civil Code of Quebec and the 1985 revision of federal statutes). In so doing, however, he stops short of providing the reader with an adequate inventory of the Dictionary's basic corpus, an unfortunate oversight because in addition to breaking ranks with established standards in terminological research, there is no way of knowing the area of law in question unless the author so discloses or the reader has prior subject-matter knowledge. Hopefully, this will be remedied in a future edition. As it stands, however, the Dictionnaire de droit québecois et canadien is a compelling and user-friendly document whose merits are far too numerous to enumerate in this article.

For instance, Professor Reid makes no attempt to sidestep controversial terms that are the touchstones of opposing schools of legal thinking. Without descending into the arena of academic imbroglios, he only attests meanings that have weathered the tempests of public usage within the spirit of the law and preponderant opinion.

In another vein, the Dictionary also displays great merit in addressing the presently inextricable problem of documenting composite terms built upon individual lexemes. Nonetheless, caveat auctor! Since this task has never been systematically vetted in the French language in Quebec and Canadian law, it is an undertaking fraught with perils. By giving readers a piece of this pie, they will soon be knocking at the door for more! A single example of how Professor Reid has opened a can of worms will suffice. On page 53, the term AVIS (notice) is defined according to the aforementioned format, thereafter the author continues by defining:

- Avis de clôture : V. CLÔTURE

- Avis de présentation : (...) notice of presentation

Avis public : (...) public notice

Quite acceptable and this information will indubitably be appreciated by many readers. But while on this subject, why not also include:

- Avis à court terme : short term notice 
Avis à long terme : long term notice

Avis consultatif : advisory opinion

- Avis d'appel additionnel : supplementary notice of appeal

- Avis d'appel : notice of appeal

- Avis d'audience sur l'état de l'instance : notice of status hearing

- Avis d'enquête : notice of enquiry

- Avis d'évaluation : notice of assessment

- Avis d'induction : constructive notice

- Avis d'intention : notice of intention

- Avis d'opposition : adverse claim

- Avis de comparaître : notice to appear

- Avis de consignation judiciaire : notice of payment into court

- Avis de contestation : notice of dispute

- Avis de contravention : contravention notice

- Avis de convocation : notice of meeting

- Avis de cotisation : assessment notice

- Avis de demande : notice of application

- Avis de désaccord : notice of contention

- Avis de dissidence : notice of dissent

- Avis de grève : strike notice

- Avis de la décision : notice of decision

- Avis de lock-out : lock-out notice

- Avis de motion : notice of motion

- Avis de poursuite : notice of action

- Avis de procès avec jury : jury notice

- Avis de proposition : notice of motion

- Avis de réception : acknowledgment of receipt

- Avis de renonciation : notice of quit claim

- Avis de requête : notice of application or notice of motion

- Avis de séance : notice of appointment

- Avis écrit : notice in writing

- Avis introductif d'instance : originating notice

- Avis juridique : legal opinion

all of legal relevance and not the least exhaustive! By supplying three expressions at random plus the many more under other entries in the Dictionary. Hubert Reid has unwittingly put his finger on a vastly undocumented area of Quebec and Canadian law and it would he abusive to expect him to shoulder the burden of resolving the dilemma. Nevertheless. his Dictionnaire de droit québécois et canadien will soon occupy a place of honor in the libraries of Quebec and Canadian legal wordsmiths. It would therefore be of the greatest assistance to all legal draftspeople to expand the purview of the Dictionary to include this unexplored terminology. Indeed, the toils of a legal lexicographer know no end!

While a few eccentrics read dictionaries for the pure pleasure of pouring over lexical discoveries, most average users only consult them for solving a problem, and the faster and more authoritative, the better. This is exactly the kind of reader to whom the Dictionnaire de droit quéhéconis et canadien caters, even to the extent of proposing words, definitions and translations impossible to find in other reputable dictionaries. To give but one example. such is the case of "entiercement" (escrow) and "entiercer" (to put into escrow) on page 281 . Since by its very essence a dictionary remains an "open set," in the 
event a desperately sought solution is not to be found the author invites readers (page VII) to bring such matters to his attention so that corrections may be made in future editions.

A specialized dictionary need not lend itself to an a priori judgment on the basis of the lexical symmetry of its entries: noun. adjective and verb. Nonetheless, in some cases it is worthwhile to recheck the data to ensure nothing is left out. In the series: aliénabilité. aliénable, aliénataire, aliénateur, aliénation, aliéné(e) mental(e) on pages 31-32, the absence of the verb aliener disturbs me because the term is far too important in legal parlance not to be illustrated. This specific case reminds us of how a corpus that is carefully staked out and explored can be of the greatest assistance to an author - either by imposing indispensable entries or eliminating irrelevant material.

Lastly, in his introduction Professor Reid explains that "the reader will note that Latin terms are generally not translated owing to the uselessness of such an operation (page XIV, my translation)." I would like to take the professor to task on this point. but in so doing I am likely to step on my own toes...

On this final note. all that remains is for me to strongly recommend all readers to become acquainted illico with this important and very complete addition to Quebec and Canadian legal documentation.

Wallace Schwab Sainte-Foy. Canada 